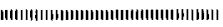

技術資料

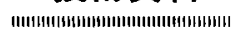

\title{
二次加工品用滑流探傷技術
}

水野正志*, 小島勝洋**

\section{Eddy Current Flaw Detection for Steel Peeled or Cold- Drawn}

\section{Masashi Mizuno and Katsuhiro Kojima}

\begin{abstract}
Synopsis
The two new technologies of the eddy current flaw detection have been developed for steel bars or wires processed after hot rolling.

The first is the rotary probe detector for peeled bars. In order to enhance the sensitivity to flaws especially on nonmagnetic ones, the applied frequency is raised to the 1 to $3 \mathrm{MHz}$ band and so the flaws deep $0.1 \mathrm{~mm}$ are readily detected.

The other is the in-line detector for the wire coil being fed into a forging machine. The rotary probe is coupled through the special transformer with air core and it is small and also light enough to follow incessantly the profile of uncoiled and then drawn wire. The computer-aided system detects flaws $0.2 \mathrm{~mm}$ or more deep just before wire cutting and rejects the product of the correspondent portion after forging.
\end{abstract}

\section{1. 緒}

渦流探偒は鉄銅業では比较的古くから用いられ ている表面きず探傷技術であるが，最近では黒皮 棒鋼の表面きす探偒に見られるよらにより浅いき ずまで探䅞できる漏洩磁束探䅞に置き代えられる 例もある。しかし，渦流探傷は(1)熱間を含む非磁 性材への暗用が可能, (2)七ンサ部の構造が比較的 简単など漏油磁束探㥂よりも優れた点がありまだ 広く用いられている。本稿ではこれらの長所を生 かした新しい用途として非磁性材料のピーリンク

1991年 8 月 11 日受付

”大同特殊銅研究開発本部, 工博

**大同特殊鋼研究開発本部
加工品とパーッフォーマによる加工直前の秦材の

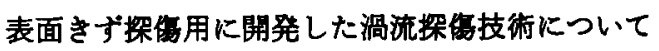
報告する。

\section{2. ピーリング加エ品用瀜流探侮}

従来, ピーリング加工品の表面きす探䇚はビー リング加工前の素材の状態で磁性材は蛍光磁粉探 傷, 非磁性材は超音波探伤と目視検查にて実施さ れていた。しかしピーリング加工前での探偪では 製品の最終的な品質保証としては不十分であり加 工後の表面きず探偒技術の開発が望まれていた。 加工後の探傷方法としては非磁性材す対象とする ことを考虑すると原理的には回転ブローブ形渦流 探傷が適している。しかし，従来の渦流探侮機で 試呀的に実施した非磁性材ビーリング品の探传で 
は良好な結果が得られなかった。この主原因は探 侮周波数の不道切さにあると考六探鹪周波数の取 適化を主体とした開発を進めビーリンタ加工品用 渦流探传技術を実用化した。

\section{1 探俉周波数の最通化}

良く知られているよらに洬電流の漫透深さは周 波数と被検查材の透磁率，電気伝迸度に依存する。 したがって，被検查材の材質ごとに周波数と渦龟 流浸透深さの成係は異なる。图 1 に各種材料の周 波数之瀜奄流浸透深さの成保を示す1)。因 1 から 明らかなよらに非磁性銅（3、ステンレス）では 磁性鋼（9．鋼，10，合金鋼）と同じ漫透深さを得 るためにはほぼ 3 桁高い周波数が必要である。

従来，磁性銅の渦流探傷では数 $10 \mathrm{kHz}$ 数 100 $\mathrm{kHz}$ の探借周波数を使用している。これから単純 に類推すれば非磁性材では数 $10 \mathrm{MHz}$ 数 100 MHz の探偤周波数が必要となる。しかしこのよ らな高周波を使用すると探偤機の粠成要素である
プローブ, 信号処理回路, 回転トランスの製作が 難しくなるので，当面これらの要素の㴶が比敕 的容易な $5 \mathrm{MHz}$ を上限として探偒機を試作し周 波数增加の奻果を実段で確認した。

图 2 にSUS 304k加エした人工きずを探偪し たときの周波数と $S N$ 比の関係を示す。 $500 \mathrm{kHz}$ の場合と比較して $1 \mathrm{MHz}$ では $S N$ 比が約 2 倍に

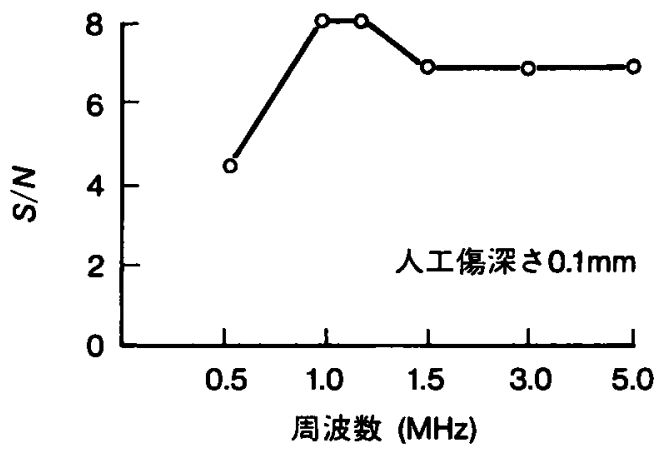

図2探偟周波数とSN 比(SUS 304丸棒)

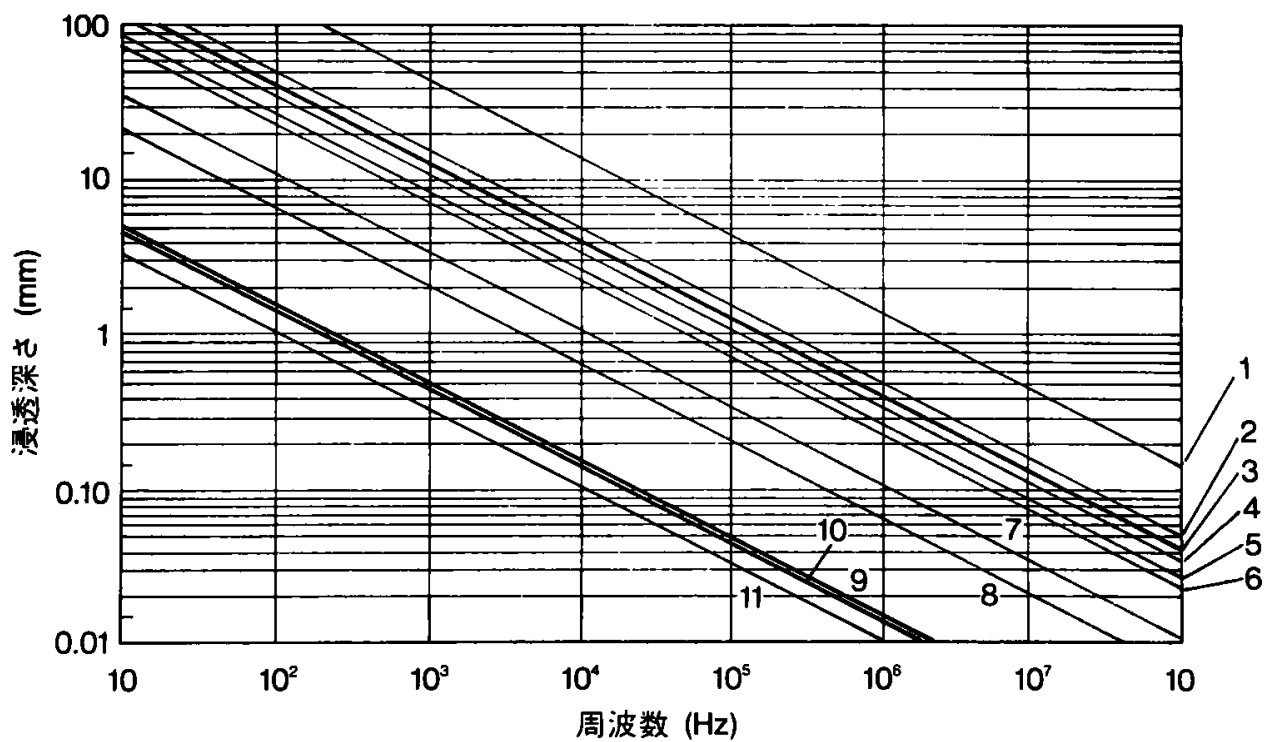

（）内固有抵抗 $(\mu \Omega-\mathrm{cm})$ ，比透磁率
1. 黒鉛 $(800,1)$
2. 水
銀 $(95.8,1)$
3. ステンレス $(70,1)$
4. シルコニウム $(50,1)$
5. ウラニゥム $(28.8,1)$
6. 鉛
$(22,1)$
7. アルミニウム $(41,1)$
8. 銅
$(1.72,1)$
9. 鋼
$(16,175)$
10. 合金 鋼 $(60,750)$
11. 純
鉄 $(11,250)$ 


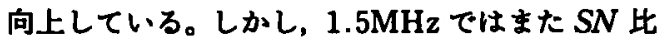
が若干低下している。四1によれば非㥞性鋼の $1 \mathrm{MHz}$ における浸透深さは約 $0.5 \mathrm{~mm}$ であり， 4 kHzにおいても0.2mmである。したがって, 深さ $0.1 \mathrm{~mm}$ の人工きずでは $4 \mathrm{MHz}$ 程度までは $S N$ 比が向上するはずである。このことを考虑すると $1.5 \mathrm{MHz}$ で $S N$ 比が減少するのは浸透深さの問題 ではなく探仿機の粠成要素の周波数特性に問題が あると考えられる。このため構成要素の周波数特 性を向上させれぱまだ $S N$ 比は向上すると考え られるが実用的なコストで製作できる構成要素の 性能には限界があるので当面 $1 \mathrm{MHz}$ の探借周波 数を採用することにした。

\section{2 自然きず探但実臥}

探鹪周波数 $1 \mathrm{MHz}$ の回転ブローブ形渦流探偖 機を試作しSUS 304 ピーリング品に故意に発生 させた自然きずを探偒し性能を確認した。結果を 图 3 に示す。被検査材を静止させた場合と比較し て走行させた場合には被検査材の震動の影管によ ク SN 比が低下しているがそれであ深さ0.1mm のきずを $S N$ 比ミ2で探㥂できている。

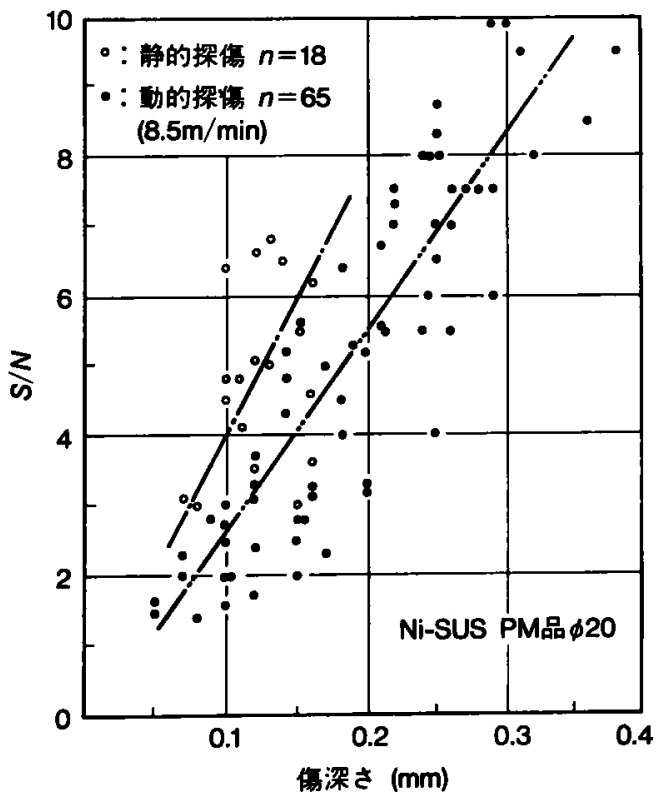

図 3 自然きず探侮結果

\section{3 实用機の紫作と探但性能}

以上の結果に基ついて非碳性材ピーリング品の 渦流探隽は実用化可能と判断し実用機を赀作し大 同特殊銅剓川崎工場に設置した。被検查材の搬送

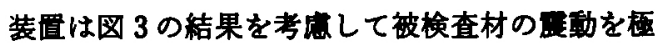
力抑制するよら工夫されている。装貫の外䍹を写 真 1 に主仕様を表 1 に示す。また，実用時におけ る探隻性能を图 4 に示す。データ数が少なく，き ず形状によって SN 比が異なるので一概には性 能を表現できないが深さ0.1mmのきずを検出す る性能は確保できていると評価できる。

\section{3. パーツフォーマ事材用焵流探但}

線材製品はそのコイル状の形状のため压延され たままの状態では表面きずが探隻できない。この ため線材製品をパーッフォーマなどで加工する場 合にはその前処理の引き抜き工程などで一時的に 直線状になる機会を利用して渦流探伤にて表面き ず探儌が実施されている。この場合，引き抜き速 度と比べて探榎速度の方が大きければ問題はない が一段的には引き抜き速度の方が大きく表面きず

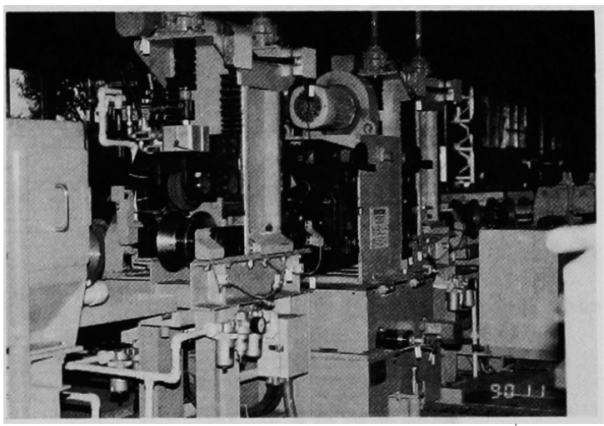

写真 1 ビーリング品用渦流探传実用機の外 镜

表 1 ピーリンク品用渦流探侮の主仕様

\begin{tabular}{|c|c|}
\hline 項 & 仕 \\
\hline 被検査材直径 & $10-110 \mathrm{~mm}$ \\
\hline 探的周波数 & $0.1,0.3,1.0,3.0 \mathrm{MHz}$ \\
\hline プロープ数 & 4 個 \\
\hline プロープ直径 & $2.5,5.0 \mathrm{~mm}$ \\
\hline 蝾速度 & $30,60 \mathrm{~m} / \mathrm{min}$ \\
\hline
\end{tabular}




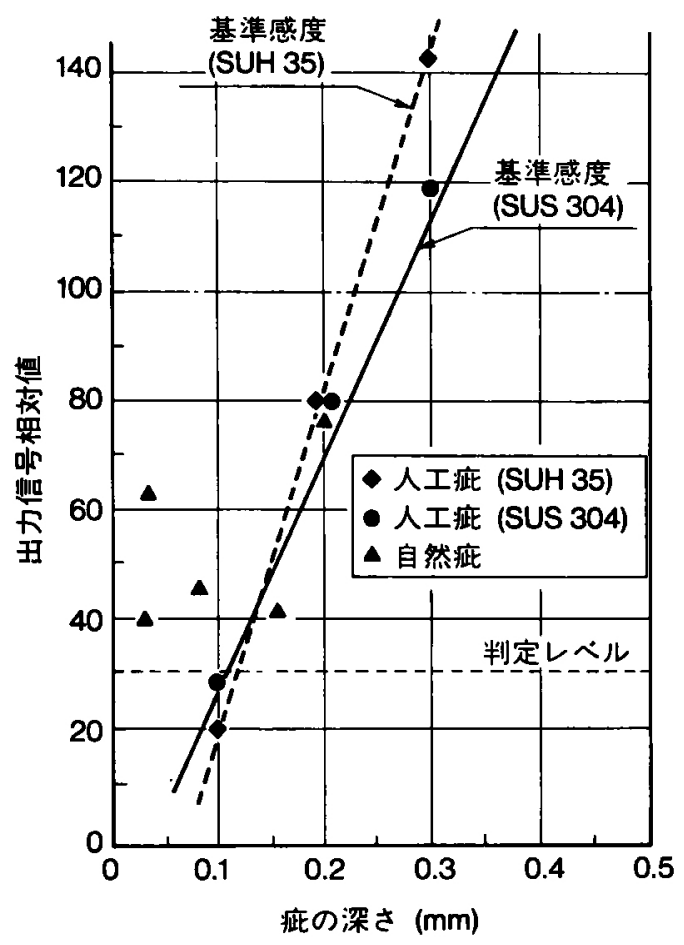

図 4 実用機の探的性能例

探稘が生産能率低下の原因になることがある。 た，最近では压延技術が進歩して線材製品の寸法 精度が向上したため引き抜きなどの前処理を必要 とせず圧延材を直接加エしょうとする傾向が出て きている。この場合には表面きずを探偤する機会 がまったくないので品質保証の面での問題が残 る。

このよらな理由により線材の表面きずをバーッ フォーマでの加工直前で探㥂できる技術が求めら れている。探賃方法としては通常の回転プローブ 形瀜流探賃が適しているがパーッフォーマ上に設 胃するため小型軽旦でかつ線材の動きに追従でき る機能が要求される。この目的で独自に開発した 空芯形回転トランスを用いてプローブ回転機構を 小型軽豆化し，さらに被検查材の上下左右の動き に追従できる做い機棬を付加したパーッフォーマ 用表面きす探偒装置を開発した。

\section{1 検出部の杬略}

\subsection{1 プロープ回転機權と做い機梳}

プロープ回転機鹤と倣い機粠の概略を图 5 に，

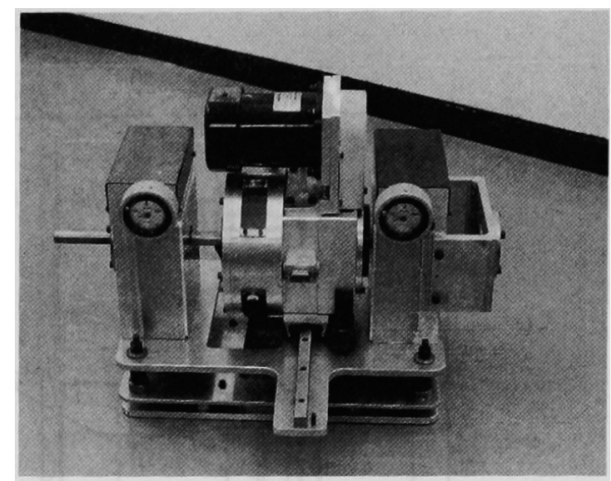

写真 2 パーッフォーー用瀜流探伤検出部の 外籍

外観を写真 2 に示す。プロープ回転機構は押さえ

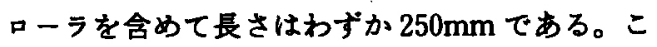
の中に後述の空芯形回転トランスが 2 チャンネル 分 6 組 (1チャンネルは送信, 受信, リフトオフ 測定用 3 組で構成) 装備されている。

その下部に設貫された做い機構は被検査材の上 下の動きにはバネにより，左右の動きにはスライ ト゚ペアリングによりブローブ回転機構を追従させ る。この機構により矯正機での矯正が不十分で曲 りのある線材にすブローブ回䢂機構が追従できる ためブロープのリフトオフが一定に保たれて SN 此が向上する。

\section{1 .2 空芯形回枟トランス}

回転機構中に装備されている空芯形回転トラン スの椣造と寸法を従来のフェライトコフ付き回転 トランスとの比較で図 6 に示す。図 6 中の試作品 はガラスエポキシ製円盤に手巻きコイルを張り付 けて製作した回伝トランスで空芯トランスの性能 確認のために使用した。完成品は性能確認後同じ くガラスエボキシ製円盤にブリントコイルを接着 したすので従来のフェライトコフ付きと比較して 体箖が約 $1 / 4$, 重量が1/11である。特に試算してな いが製作費す大幅に低減している。

試作および完成品の信号佉達特性を図 7 に示 す。プリントコイルでつくられた完成品は 4MHzにおいてもほぼ70\%の伝達率があり，送 受信両方にこのトランスを使用してす総合の伝達 率は約50\%となり十分な性能である。試作品との 云達率の差は同じェイル間隔でるコイルの断面形 


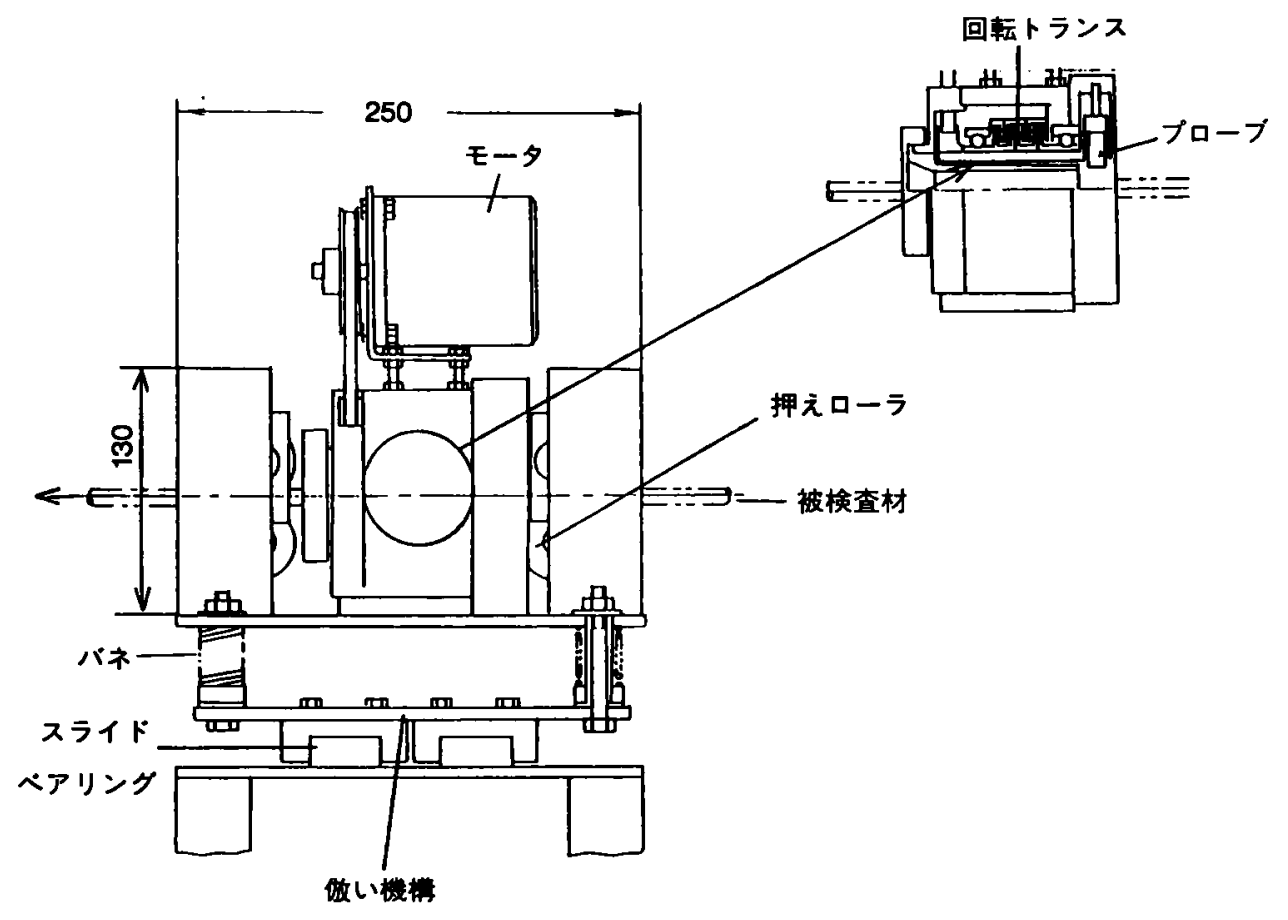

因 5 パーッフォーマ用渦流探偟機検出部

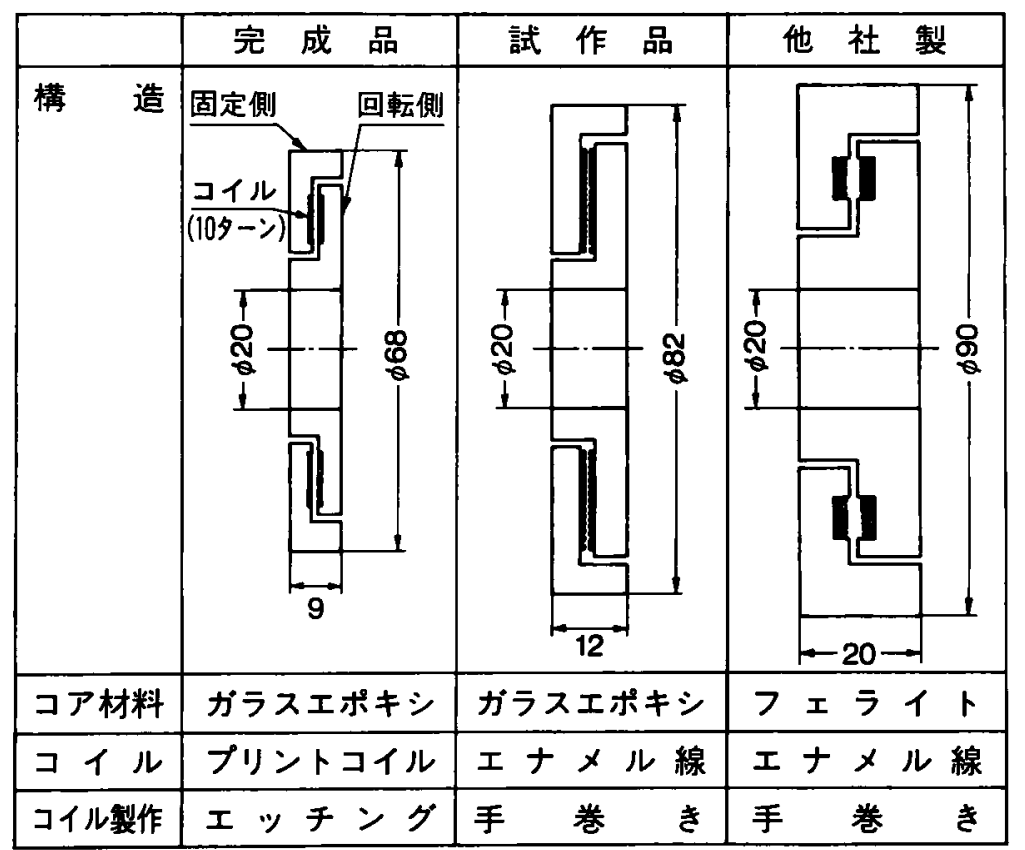

因 6 回転トランスの比较 


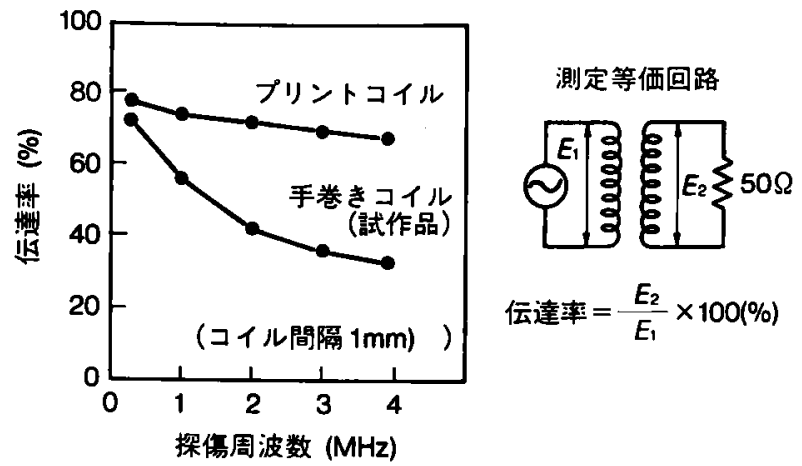

因 7 空芯形回転トランスの信号伝達特性

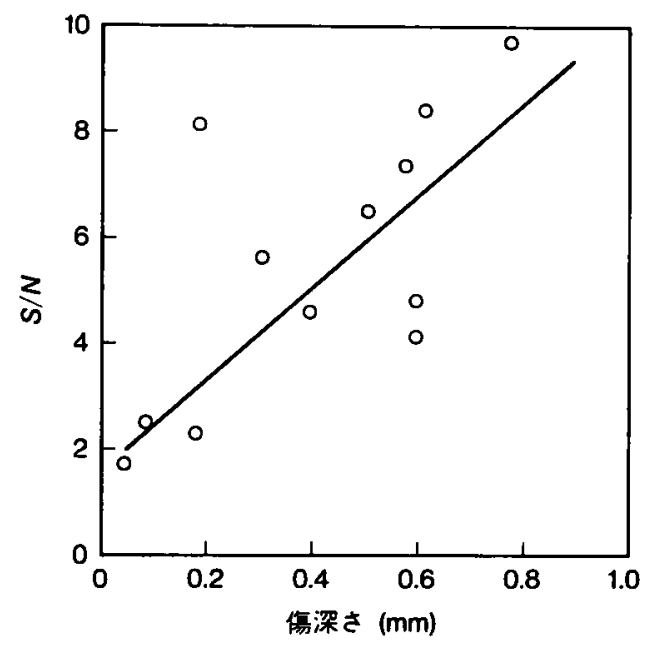

図 8 パーッフォーー用瀜流探借装置の探侮 結果例

状の違いにより生ずる実質のコイルの間隔の差に 起因するものである。

\section{2 探保性能}

この装置を実㻮のバーッフォーマに設置して探 侮した結果を图 8 に示す。また主仕様を表 2 に示 す。深さ0.2mm のきずが $S N$ 比 3 で検出できて いる。本装置では表 2 にあるように磁性材探侮 時には外部磁化䒾置を用いた磁気飽和により被検 查材表面の磁気特性むらを軽減し $S N$ 比を向上 させている。当然，探終了後には眖磁できる機 能を備えている。
表 2 バーッフォーマ用洞流探儌の主仕样

\begin{tabular}{|c|c|}
\hline 項 & 様 \\
\hline 被検 查材 直经 & $5 \sim 20 \mathrm{~mm}$ \\
\hline 探伤 周 波 数 & $1 \mathrm{MHz}$ \\
\hline 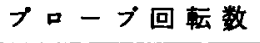 & $1600 \mathrm{rpm}$ \\
\hline プ ロ & 2 個 \\
\hline プロープ直经 & $2.5 \mathrm{~mm}$ \\
\hline ブローブリフトオフ & $0.5 \mathrm{~mm}$ \\
\hline 外 部 化 力 & $2 \mathrm{~A} \times 500$ ターン \\
\hline
\end{tabular}

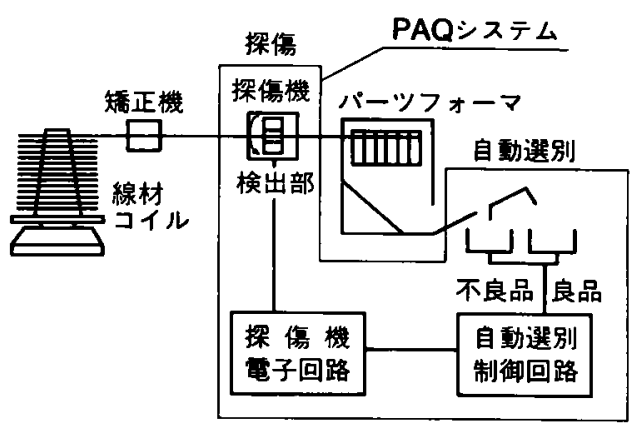

図 $9 \mathrm{PAQ}$ システムの構成

\subsection{PAQ システム}

開発した探侮装置ときず信号判定装置およびき す部選別装置を組及合わせて表面きず検出一選別 システムである PAQ (Perfect Assurance of wire Quality）システムを作り上げた。このシス テムは探信機で挨出した素材のきず部を良品部之 
同じよらに切断，加エした後製品排出口で選別し て排除するるのである。このシステムの構成の概 略を图 9 に示す。選別制御回路は検出されたきず 部が製品排出口に到達するタイミンクを計算して きず部が加工された製品が到達するタイミングに 選別レバー駆動信号を出力する。このシステムに より王延したままの線材ですきず部の自動排除が 可能になり不良品の浘入を防止することができ る。

\section{4. 桔}

F

渦流探偒の新しい適用方法として非珄材ピー リンク品の探侮とパーッフォーマ素材の探侮の例
を举げ説明した。これらの例が示すよらに渦流探 愎のこれからの発展の方向は熱間材を含む非磁性 材への適用と低価格化によるより広い簿囲への適 用である。また，表面状態の良好な非磁性材料に 対してはさらに高い探侮周波数を適用してより小 さなきずが探偒できる方向へと発展すると思われ る。
（文
嗝）

1）日本非破堘検查㙝会編：非破壤検査便覧， (1978)，652 [日刊工業新聞社] 